\title{
An Analysis Report On: Soil Liquefaction and the most effective and economical Mitigation Measure for Low-story Residential Buildings in Kathmandu Valley
}

\author{
Pratik Sapkota ${ }^{1}$ \\ ${ }^{1}$ Affiliation not available
}

July 16, 2020

\begin{abstract}
This analysis report is an attempt to differentiate various mitigation techniques for soil liquefaction that are currently in practice around the world. Through the different data- obtained from separate researches, this report strives to determine the most efficient and economical mitigation measure for low-story (3,4 floors) residential buildings in the Kathmandu valley. The disastrous earthquake of April 2015 left many residents of Kathmandu valley awestruck. The houses in the Imadol, Manamaiju, Manahara, Ramkot, and Changu Narayan were hugely damaged. This report is an effort to raise awareness, among engineers and other people, that geotechnical failures such as liquefaction are significant aspects of structural stability, despite being overshadowed by the superstructure.
\end{abstract}

\section{Hosted file}

Report on Soil Liquefaction.docx available at https://authorea.com/users/343500/articles/ 470239-an-analysis-report-on-soil-liquefaction-and-the-most-effective-and-economicalmitigation-measure-for-low-story-residential-buildings-in-kathmandu-valley 